\title{
IBN MASARRA A TRAVÉS DE LAS FUENTES: OBRAS HALLADAS Y ESCRITOS DESCONOCIDOS
}

\author{
PILAR GARRIDO CLEMENTE1 \\ Universidad de Murcia
}

\section{Resumen}

Este artículo consta de tres partes. La primera es una exposición comentada de los datos más relevantes contenidos en las fuentes sobre la vida del pensador andalusí Ibn Masarra al-Ŷabalī (883-931 d. C.). En la segunda parte se presenta un breve estudio crítico sobre las referencias actualmente disponibles acerca de los siete títulos atribuidos al autor: dos obras conocidas, al menos tres por el momento desconocidas y un apócrifo. La tercera parte ofrece la traducción íntegra comentada de la noticia que Ibn Ḥārit al-Jušanī (m. 971) dedicó a Ibn Masarra en su Historia de los alfaquíes y tradicionistas de al-Andalus (Ajbār al-fuqahä’ wa-l-muhaddițīn).

Palabras claves: Pensamiento andalusí. Ibn Masarra. Sufismo. Biografía. Al-Andalus.

\begin{abstract}
The present article includes three sections. The first one is an exposition of the most relevant data provided by the sources on the life of the Andalusian thinker Ibn Masarra al-Ŷabali (883-931). The second section offers a brief critical study on the main references we have today about the seven titles attributed to the author: two known works, at least three unknown writings and an apocryphal. The third section provides a full commented translation of Ibn Masarra's biography written by Ibn Ḥārit alJušanī (d. 971) in his History of the judges of al-Andalus (Ajbār al-fuqahä̀ wa-l-muhaddițīn).
\end{abstract}

Keywords: Islamic thougth. Ibn Masarra. Sufism. Biography. Al-Andalus.

1 Profesora de la Universidad de Murcia. Correo-e: pilucagc@hotmail.com. Recibido 10-02-2009; segunda versión: 14-04-2009. 


\section{REFERENCIAS SOBRE LA VIDA DE IBN MASARRA}

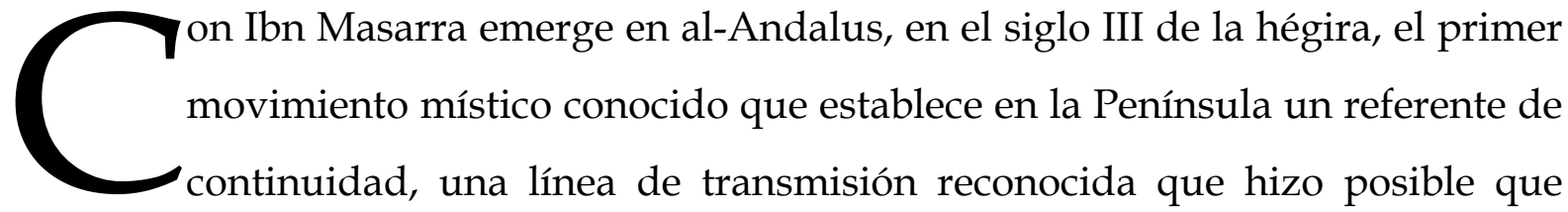
sufíes andalusíes más tardíos, como Ibn 'Arabī de Murcia, que tanto valoró el sufismo andalusí como manifiesta en diversas obras², Ibn al-Mar'a ${ }^{3}$ o al-Šuštarī de Guadix ${ }^{4}$, cuenten a Ibn Masarra entre los grandes maestros cuyo influjo han recibido.

¿Qué sabemos de la vida y la obra de este pensador a quien Ibn 'Arabī consideró “uno de los más grandes entre los hombres de la Vía (min akbar ahl al-

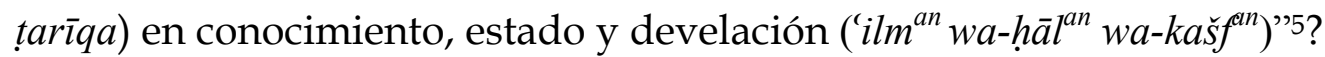

Abū 'Abd Allāh Muḥammad b. 'Abd Allāh b. Masarra b. Naŷīh al-Qurțubī alŶabalī, nació en Córdoba, entonces capital del emirato omeya, el año 269/883, de una familia de origen mawlà (clientes bajo patronato) ${ }^{6}$. En su alquería de las estribaciones de la Sierra de Córdoba falleció el 4 de šawwāl de 319 H. (19 de octubre de 931 d. C.).

\footnotetext{
2 V., especialmente su R. Rūh al-quds, obra traducida al español por M. Asín Palacios con el título de Epístola de la santidad: Vidas de santones andaluces, Madrid: Hiperión, 1981 (1 ${ }^{\mathrm{a}}$ ed. 1935), y más tarde al inglés, por R. W. Austin, con el título Sufis of Andalucia, Londres: George Allen \& Unwin, 1971.

${ }^{3}$ Abū Isḥāq Ibn al-Mar’a, maestro de Ibn Sabīnn, que comentó el Iršăd de al-Ŷuwaynī. Véase L. Massignon, Recueil de textes inédits, París, 1929, p. 70; R. Ramón Guerrero, "IBN MASARRA”, en J. Lirola Delgado y J. M. Puerta Vílchez (ed.), Biblioteca de al-Andalus: De Ibn al-Labbāna a Ibn al-Ruyūlè [Enciclopedia de la Cultura Andalusí, I] 4, (Almería: Fundación Ibn Tufayl de Estudios Árabes, 2006), nº 788, p. 150; y C. Addas, "Andalusī Mysticism and the Rise of Ibn 'Arabī", en The Legacy of Muslim Spain, ed. S. Khadra Jayyusi, Leiden: Brill, 1993, vol. II, p. 916 y nota 35.

${ }^{4}$ V., p. ej., (al-Šuštarī, 2004: 21) al-Risāla al-Šuštariyya, 'Adlūnī (ed.).

${ }^{5}$ V. (Ibn 'Arabī, s.d., I: 226 cap. 13), al-Futūhāt al-makkiyya.

${ }^{6}$ V. (Ibn al-Faraḍī, 1892) Ta’rīj 'ulamā' wa-l-ruwāt li-l-ilm bi-l-Andalus, y (Asín, 1914, I: 39-41) Abenmasarra y su escuela. Orígenes de la filosofía hispanomusulmana.
} 
Aunque bastantes fuentes y repertorios bio-bibliográficos recogen datos y noticias sobre Ibn Masarra7, principalmente el Tảrīj de Ibn al-Faraḍ̄ (m. 403/1012), el Muqtabas de Ibn Ḥayyān (m. 469/1076) y, ya en el siglo XIII, la Takmila de Ibn al-Abbār (m. 1260), poco se sabe en realidad de su vida.

'Abd Allāh b. Masarra, su padre, versado y reconocido transmisor de hadices, viajó por Oriente y los santos lugares en dos ocasiones, familiarizándose con las corrientes de pensamiento de la época. En Basora estuvo al parecer en contacto con círculos mu'tazilíes. A su regreso a al-Andalus se le atribuyeron doctrinas qadaríes (en particular la profesión de la doctrina del libre albedrío). Según al-Faraḍī, era amigo del mu'tazilí cordobés conocido como Jalīl al-Gaflå ${ }^{8}$.

En cualquier caso, como comenta Claude Addas remitiendo a un trabajo inédito de James Morris que revisa las fuentes relativas a Ibn Masarra, el término

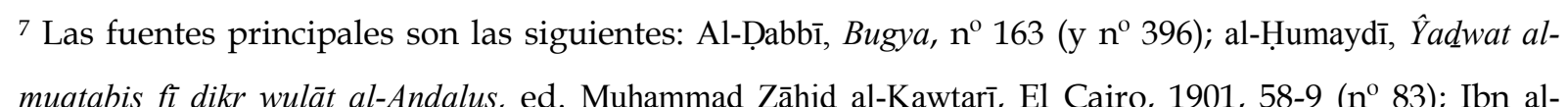
Abbār, Takmilat al-șila, ed. Codera, no 113, 186, 326, 339 y 347; Idem, ed. A. Bel y M. Bencheneb, Argel, 1920, no 8, 17, 529, 530 y 562; Ibn al-Faraḍī, Tảrīj, no 650 y 1202; Ibn Farhūu, Dībā̂̂y (ed. El Cairo), p. 47; Ibn Ḥārit al-Jušanī, Ajbār, no 209; Ibn Hayyān, Muqtabis/Muqtabas V, 19-21/35-8 (cita dos versiones de la biografía de Ibn al-Faraḍī); Ibn Jāqān, Maṭmaḥ, ed. Constantinopla, 1302 H., p. 58; al-Maqqarī, Naf̣̣ al-țīb, ed. I. 'Abbās, Beirut, 1968, II, p. 354; Șāiid al-Ṭulayṭulī, Ṭabaqāt al-umam, ed. Cheikho, Beirut, 1912, p. 21 (cuya noticia retoma Ibn al-Qifțī, Tảrīj al-ḥukamā̄, 16); Šams al-Dīn al-Qurțubī, al-Tadkira fì aḥwāl almawtà, Beirut, s. d., p. 341. A estas noticias han de añadirse, desde luego, las recogidas por Ibn Hazm en al-Fiṣal fì l-milal, El Cairo, 1903, II, pp. 128-29, IV, pp. 198-200, y IV, p. 80, y en Futūhāt makkiyya (v. Índice, vol. IX, ed. Beirut, s. v.) y otras obras de Ibn 'Arabī.

Las noticias de al-Ḍabb̄̄, Ibn Jāqān y al-Maqqarī reproducen más o menos en los mismos términos la de al-Humaydī que, sin aportar mucha información, se hace eco de la corriente adversa a Ibn Masarra presentándolo como innovador. V. (Lévi-Provençal, 1954: 78) “A propos de l'ascète philosophe Ibn Masarra de Cordoue", en Donvm Natalicivm H. S. Nyberg Oblatvm, Orientalia Suecana, XXVIII, Uppsala. Como detalles interesantes, al-Humaydī comenta en su noticia que los escritos de Ibn Masarra contienen "alusiones sufíes" (išārāt șūfiyya) y, entre otras cosas, cita cuatro breves versos que el autor habría dirigido a un tal Abū Bakr al-Lu'lu'ī, invitándole a ir a visitarle un día en que llovía.

8 Sobre este personaje y su relación con Ibn Masarra, v. M. Fierro, La heterodoxia en al-Andalus durante el período omeya, Madrid: IHAC, 1987, esp. pp. 91-93 y 112. 
'Mu'tazila' "was at this time used as a convenient blanket term for a huge area of theological or philosophical ideas regarded as suspect because they failed to fit the rigid framework of Mālikī orthodoxy, and the suspicion of Mu'tazilism attached to Ibn Masarra and those around him (beginning with his father) should not be taken literally"9. Comparto con Morris la idea de que la atribución de la condición de mu'tazilí no ha de interpretarse literalmente en el contexto malikí de al-Andalus.

Muḥammad estudió en Córdoba, primero, con su padre, y luego con Muhammad b. Waḍạạh (m. 287/900)10, uno de los primeros y más ilustres jurisconsultos de la escuela malikí en al-Andalus, importante transmisor de hadices y de la práctica del ascetismo $(z u h d)$ a la Península, quien pudo haber conocido a sufíes orientales como Ḍū l-Nūn (m. 245/859), Sarī al-Saqatī (m. 253/867) o Bišr al-Ḥāfì (m. 227/841)11, o bien a sus discípulos. Según al-Faraḍī, estudió también con al-Jušanī. Se entiende que se trata del transmisor de hadices Muhammad b. 'Abd al-Salām al-Jušanī12, con quien su padre había viajado a Oriente compartiendo con él buen número de maestros. Tanto Ibn Waḍ̣āḥ como Ibn 'Abd al-Salām al-Jušanī -que residió en Oriente al menos veinticinco años ${ }^{13}-$, pudieron transmitir a Ibn Masarra doctrinas ascéticas, contemplativas y esotéricas de Oriente.

'Abd Allāh, el padre de Ibn Masarra, falleció en La Meca el año 286/899-900. Su hijo Muhammad tenía entonces diecisiete años.

Sin más noticias relevantes sobre su formación, algunos biógrafos nos presentan ya a Ibn Masarra en los últimos años del emirato de 'Abd Allāh, hacia el 300

\footnotetext{
9 V. C. Addas, “Andalusī Mysticism”, p. 913.

10 Sobre esta figura v. Fierro, Heterodoxia, pp. 41-44, 80-85, 90-94, 10-103, 113, 120, 127 y 130 ; y A. Carmona, "The Introduction of Mālik's Teachings in al-Andalus", en The Islamic School of Law: Evolution, Devolution and Progress (ed. P. Bearman, R. Peters y F. Vogel), pp. 50 y 56.

11 Sobre estos conocidos personajes véanse, p. ej., las correspondientes entradas de la Encyclopédie de

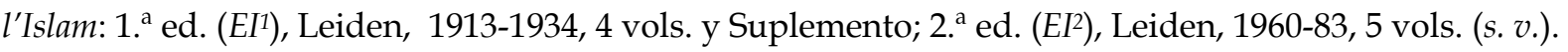
12 Sobre él, v. Fierro, op. cit., pp. 81, 88-91, 112-113, 120, 127 y 138.

${ }^{13}$ V. a este respecto la reflexión de C. Addas, "Andalusī Mysticism”, p. 914.
} 
ó 301 (912-914), con unos treinta años, viviendo en las estribaciones de la Sierra de Córdoba en compañía de sus discípulos allegados.

Según una noticia de la Takmila de Ibn al-Abbār (m. 638/1260), sus compañeros conocidos procedían, principalmente, de Córdoba y Toledo14. Ibn al-Abbār los presenta en su mayoría como devotos ascetas ${ }^{15}$ empleando los términos wari', nāsik o zāhid, comunes en los repertorios biográficos para referirse, en general, a los espirituales contemplativos.

Con posterioridad al viaje de su padre -con quien al parecer no se encontró en Oriente-, aunque no sabemos cuándo exactamente, Ibn Masarra peregrinó a su vez a La Meca, acompañado por algunos discípulos andalusíes, entre los que se contaban Muḥammad Ibn al-Madīn̄̄ y Muḥammad Ibn Wahb Ibn al-Ṣayqal al-Qurțubīîn.

\footnotetext{
${ }^{14}$ Su información se basa en la obra del perdido K. Ajbār Ibn Masarra wa-așhābi-hi que, como señala E. Lévi-Provençal, no se menciona en ninguna otra fuente. V. Lévi-Provençal, "A propos de l'ascète philosophe Ibn Masarra de Cordoue", en Donvm Natalicivm H. S. Nyberg Oblatom, Orientalia Suecana, XXVIII Dic., Uppsala, 1954, p. 81. Este artículo constituye una temprana y fundamental aportación al estudio crítico de la biografía de Ibn Masarra y las fuentes que la recogen. Entre otras contribuciones, el autor analiza seis biografías adicionales de discípulos de Ibn Masarra contenidas en la Takmila a las cuales no tuvo acceso Asín al realizar su investigación debido a que no constaban en la edición entonces disponible y sólo se publicaron, como suplemento, con posterioridad a su trabajo, en la edición de Bel y Bencheneb. V. también Addas, “Andalusī Mysticism...”, p. 915 y nota 22.

Lévi-Provençal hace notar, con relación a la visión que Ibn Ḥazm tenía de Ibn Masarra y a la inclusión de los masarríes en la noticia de Ibn al-Faraḍī, lo siguiente: "Como más tarde Ibn Ḥazm, que en su famosa Epístola sobre la excelencia de al-Andalus no dudará en citar a Ibn Masarra entre las más grandes celebridades de su país, aunque se cuide de precisar que 'no concuerda con su sistema' [se remite a Maqqarī en nota], Ibn al-Faraḍī no excluyó deliberadamente de sus listas a aquellos compatriotas que la inquisición de los alfaquíes cordobeses había maltratado en el siglo X". Op. cit., p. 76. La traducción, como siempre que no se indique otra cosa, es mía.

${ }^{15}$ Como señala Addas, es interesante notar que en el Tárīj de Ibn al-Faraḍī, sin embargo, esta connotación no aparece en las biografías relativas a la segunda generación de discípulos. V. Addas, op. cit., p. 915.
}

${ }^{16}$ Sobre sus biografías, v. Lévi-Provençal, op. cit., pp. 79 y 81. 
Por una noticia de Ibn 'I $\operatorname{da}^{\mathrm{r}} \overline{1}^{17}$, sabemos que con ellos se detuvo en Qayrawān, donde asistió a la clase del alfaquí malikí Aḥmad b. Naṣr b. Ziyād, coincidiendo allí con el alfaquí cordobés Muḥammad b. Ḥārit al-Jušanī -autor de la obra Ajbār al-fuqahä wa-lmuhadditīn, en la que dedica a Ibn Masarra la noticia que se traduce íntegramente más adelante-, quien no le había conocido personalmente con anterioridad a este encuentro.

Visitó después La Meca, donde conoció al sufí Abū Sa īd Ibn al-A'rābī (m. 341/952), discípulo de al-Ŷunayd, y tal vez se encontró también con el maestro Abū Ya'qūb al-Nahraŷūrī (m. 330/941) ${ }^{18}$. Allí pudo también recibir noticias, tal vez directamente de sus discípulos, de la enseñanza de Dū 1-Nūn al-Mișrī y Sahl al-Tustarī, los dos célebres sufíes, reputados tradicionalmente por su conocimiento de la ciencia de las letras, a quienes Ibn Masarra cita repetidamente en su K. Jawāṣs al-ḥurūf mostrando la importancia de su decisivo influjo.

En Medina recorrió, como otros peregrinos, los lugares donde vivió el Profeta. Según su compañero Ibn al-Madīn̄̄, manifestó especial interés por la casa de Māriya, su concubina copta, y tomó nota de las dimensiones de una de sus dos habitaciones superiores, cuya estructura reprodujo luego a su regreso en su morada de Córdoba ${ }^{19}$.

No se sabe cuándo volvió a al-Andalus de este viaje, pero se supone que fue ya iniciado el gobierno de 'Abd al-Raḥmān III.

Según la interpretación tradicional de su nisba, su vida retirada en su propiedad de la Sierra, adonde acudían sus discípulos, lejos de la vida urbana, le

\footnotetext{
17 Ibn 'İāāī, Bayān, I, 194-95. V. Asín, Abenmasarra, p. 45; Lévi-Provençal, op. cit., p. 81, notas 2 y 3. 18 Sobre estos célebres sufíes, véanse, p. ej., las correspondientes entradas de la Encyclopédie de l'Islam (s. v.), así como las referencias que sobre Ibn al-A'rābī en particular se dan en la nota 36 más adelante. ${ }^{19}$ Más precisiones pueden consultarse en Lévi-Provençal, “À propos de l'ascète...", pp. 79-80. Fierro

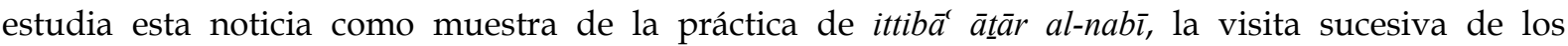
monumentos y restos relacionados con la vida del Profeta. V. Fierro, "Una refutación contra Ibn Masarra", Al-Qantara, X, 1989, pp. 273-75.
} 
valió el apelativo de al-Ŷabalī, "el Serrano". No obstante, cabe considerar la posibilidad de que el autor hubiera nacido en algún lugar cuyo nombre comenzara con el término $\hat{Y} a b a l$, 'Monte', y el apelativo fuera un auténtico patronímico.

La difusión de la enseñanza de Ibn Masarra atrajo el recelo de los alfaquíes vinculados al poder que le atribuyeron diversas desviaciones doctrinales. Desde los últimos años del califa 'Abd al-Raḥmān III, se llegó a condenar en varias ocasiones a los seguidores de Ibn Masarra ${ }^{20}$ quien, con anterioridad, ya había fallecido en el sosiego de su morada a la edad, según al-Faraḍī, de cincuenta años y tres meses.

En principio, de las fuentes se deduce que, desde su vuelta a al-Andalus, Ibn Masarra no sufrió acoso ni persecución y pudo transmitir su enseñanza sin que le molestaran ${ }^{21}$.

De la elocuencia de Ibn Masarra comenta Ibn Hayyān lo siguiente: “Su expresión era suave y aguda, lo que le permitía componer el discurso embelleciendo las palabras [...]; con su dulzura de expresión, solidez dialéctica, penetración exacta de los conceptos y variados conocimientos arrebataba las mentes [...]; compuso libros excelentes y difundió acertadas epístolas..."22.

\footnotetext{
${ }^{20}$ No me ocuparé en esta breve presentación ni de los discípulos, ni de la posteridad de Ibn Masarra, ni de la literatura de refutación del pensamiento del sufí cordobés de la que nada se ha conservado salvo vagas noticias, ni de la quema de libros o las persecuciones antimasarríes acaecidas tras su muerte. Sobre estos temas, que ya han sido tratados extensamente, v. Lévi-Provençal, op. cit., pp. 8183; Fierro, Heterodoxia, esp. pp. 110-118 (sobre Ibn Masarra) y 132-140 (sobre la persecución contra los masarríes), y también su nota "Una refutación contra Ibn Masarra", Al-Qanțara, X, 1989, pp. 273-75; y Cruz Hernández, "La persecución antimasarrí durante el reinado de 'Abd al-Raḥmān al-Nāṣir li-Dīn Allāh según Ibn Ḥayyān", Al-Qanțara, Madrid, 2 (1981), pp. 51-67, y 3 (1982), pp. 483-484.

${ }^{21}$ V., p. ej., Lévi-Provençal, p. 81; Fierro, Heterodoxia, p. 118. Según Addas, tampoco hay razón de peso para asumir que con anterioridad fuera acusado y forzado a salir de al-Andalus: "There is no reason [...] to suppose (as Ibn al-Faraḍī's informant does) that Ibn Masarra was actually accused of zandaqa, or heresy, in his own lifetime, and forced to "flee" al-Andalus". Addas, op. cit., p. 914.

22 Véase M. J. Viguera y F. Corriente, Crónica del califa 'Abdarrahmāan III an-Nāṣir entre los años 912 y 942 [Ibn Ḥayyān, al-Muqtabas V], Zaragoza, 1982; Muqtabas, Madrid, 1979, V, 21/37 y 11-12/26-7). El texto
} 
Por diversas razones que ya se han analizado con profundidad en estudios críticos previos ${ }^{23}$, algunas fuentes primero y, más tarde, orientalistas como Dozy, Goldziher ${ }^{24}$ o Asín Palacios en su célebre ensayo sobre el autor, han recreado literariamente, con vagos testimonios indirectos, conjeturas e hipótesis en ocasiones sin fundamento, una figura marcadamente polémica caracterizada por diversas formas de "heterodoxia": presunta adscripción cripto-ismaelí, supuesto influjo del Pseudo-Empédocles, etc. Sin embargo, a mi parecer, el Ibn Masarra forjado por estos ilustres orientalistas a partir de esas fuentes no se corresponde con el Ibn Masarra que conocemos a través de sus textos y a la luz de las noticias y estudios menos dados a la polémica.

Pensemos por un momento qué se sabría, por ejemplo, de Ibn 'Arabī de Murcia si sólo lo conociéramos por el testimonio de detractores como Ibn Taymiyya o incluso

aparece también citado y comentado en Fierro, Heterodoxia, pp. 114-115. No reproduzco aquí las severas críticas que acompañan a estas amables expresiones relativas a su oratoria.

${ }^{23}$ V., entre otros, Addas, "Andalusī Mysticism...", pp. 912-913; R. Ramón Guerrero, "Ibn Masarra, gnóstico y místico andalusí", en Las raíces de la cultura europea. Ensayos en homenaje al profesor Joaquín Lomba (ed. J. Solana), Zaragoza: Prensas Universitarias de Zaragoza-Institución Fernando el Católico, 2004, pp. 231-233; S. M. Stern, “Ibn Masarra, follower of Pseudo-Empedocles - an Illusion” en Actas IV Congreso de estudios árabes e islámicos, Coimbra-Lisboa (1968), Leiden: J. Brill, 1971, pp. 325-328; y P. Lory, “Ibn Masarra”, en Dictionnaire critique de l'ésotérisme, ed. J. Servier, París: PUF, 1998, p. 633.

Véase también, en este sentido, mi Tesis Doctoral aún inédita, titulada Estudio, traducción y edición de la obra de Ibn Masarra de Córdoba, Universidad de Salamanca, 2007, cap. IX, que está en proceso de edición en formato CD-ROM. En este estudio, al hacer una edición cuidada de las obras de Ibn Masarra y traducirlas íntegramente, mi propósito central ha sido conocer y dar a conocer al autor directamente por medio de sus escritos, los cuales nos revelan a un original pensador musulmán de clara inspiración sufí que, como Ibn 'Arabī más tarde, considera el uso de la razón un imperativo coránico.

24 Dozy, Histoire des musulmans d'Espagne jusqu'à la conquête de l'Andalousie par les Almoravides (2a ed. por Leví-Provençal, Leiden, 1932, 3 vols.), vol. II, p. 127; Goldziher, Introduction au Livre d'Ibn Toumert, Argel, 1903, pp. 68-69. Ya he tenido ocasión de debatir diversas adscripciones y tesis polémicas atribuidas a Ibn Masarra. Véase, por ejemplo, P. Garrido, “Textos relativos al Trono en la obra de Ibn Masarra", en El viaje interior entre Oriente y Occidente (ed. P. Beneito y P. Garrido), Madrid: Mandala (Alquitara), 2008, pp. 134-147. 
por las opiniones de orientalistas como el ilustre estudioso del sufismo Louis Massignon que no llegó a apreciar el alcance y la significación de su obra.

\section{OBRAS DE IBN MASARRA}

Siete son los títulos que, según las noticias conocidas, se han atribuido a Ibn Masarra. Corresponden, en principio, a seis escritos distintos. De ellas, sólo dos obras del autor (números 1 y 2 ) son actualmente conocidas $\mathrm{y}$, hasta el momento, unánimemente reconocidas como auténticas.

Al menos otras tres, que se mencionan a continuación (3-5), son obras por el momento perdidas, y también se le ha atribuido una obra apócrifa que se menciona al final (6).

\section{[Obras conocidas]}

\section{El K. Jawāṣṣ al-ḥurūf o 'Libro de los significados de las letras':}

Es el escrito más amplio conocido de Ibn Masarra y también su contribución más original e importante con relación a la historia del pensamiento sufí. Este tratado, titulado así en el único manuscrito conservado, se cita en la obra de Ibn 'Arabī con el título abreviado de K. al-Hurūfo ‘Libro de las Letras'25.

En su K. Jawāṣs al-ḥurūf, Ibn Masarra no trata de las veintiocho letras del alfabeto o alifato árabe, sino únicamente de catorce, la mitad de ellas. Se trata de las llamadas letras iniciales ( $a w \bar{a} i l$ al-qur'ān o fawātih) con que comienzan veintinueve azoras coránicas. Estas letras han suscitado diversas interpretaciones tanto exotéricas como esotéricas y han constituido uno de los principales y constantes estímulos del desarrollo de la ciencia de las letras en el Islam. Además de las denominaciones de

\footnotetext{
${ }^{25}$ Ibn 'Arabī, al-Futūhāt al-makkiyya, vol. IV (ed. Beirut: Dār al-Kutub al-'Ilmiyya, en IX vols.), cap. 272, pp. 315-316. Sobre esta obra masarrí, v. P. Garrido, "Edición crítica del K. Jawāṣs al-ḥurūf de Ibn Masarra", al-Andalus-Magreb: Estudios Árabes e Islámicos, Universidad de Cádiz, Cádiz, no 14 (2007), pp 51-89.
} 
$a w \vec{a} i l$-que remite a su condición de principios- y fawātih -término que evoca llaves que abren, claves que cifran y descifran, aperturas espirituales-, estas catorce letras, correspondientes simbólicamente a las catorce mansiones del plenilunio, se llaman también letras aisladas (muqața'a), porque tradicionalmente se recitan pronunciando su nombre -por ejemplo, alif lām-mìm-, como letras separadas que, aunque están gráficamente unidas, no forman palabras. Por otra parte, también están en cierto sentido 'separadas' de las demás letras y del resto del texto coránico por esta condición exclusiva que las distingue del lenguaje común.

Ibn Masarra las llama también letras ocultas o internas (bātina), por oposición a las otras catorce, que serían manifiestas o externas (ẓāhira). Se entiende que las primeras -en su condición de letras no articuladas en palabras- corresponden al dominio espiritual del divino Misterio (gayb), mientras que las segundas pertenecen al mundo del testimonio ('ālam al-šahāda) es decir, al ámbito de la manifestación del lenguaje articulado.

El autor establece en la introducción a la obra una directa correspondencia entre los grados de las letras misteriosas, que son las aleyas por excelencia, las aleyas del Corán en general, los Nombres divinos comunicados por la profecía, los grados de la progresión espiritual y los grados del Paraíso, todo lo cual se compara a una escala.

Según se desprende del discurso masarrí, el sentido esotérico de las letras, debido a su elevada condición en tanto que principios de la creación, permanece oculto a la comprensión exotérica ordinaria. Para entender la importancia de este tratado, nótese que Ibn Masarra ha sido el primero en la historia del pensamiento islámico transmitido en los textos conocidos que ha interpretado separadamente el conjunto de las letras misteriosas del Corán, de forma metódica, con una visión global unificadora. El autor de Jawāṣs al-ḥurūf explica, clasifica y relaciona la totalidad de estas letras, estableciendo categorías, grados y correspondencias coherentes en una integradora logovisión que las presenta como referente escriturario fundamental de la ontología y la cosmología islámicas. 
El K. Jawāṣs al-hurūf es también la primera exégesis general de las secuencias de letras misteriosas que las explica en su contexto coránico, tanto con relación a los pasajes concretos en que se encuentran -la aleya o conjunto de aleyas a cuyo contenido están, en particular, plenamente vinculadas-, como con relación a la posición en que aparecen con respecto a las otras secuencias según el orden de las azoras en que figuran. De hecho, el autor dedica dos secciones a la interpretación de las letras en tanto que grados en función del orden en que aparecen: en la primera enumeración la exégesis sigue un orden numéricamente ascendente, pero ontológicamente descendente, desde el alif (Sura 2) hasta la nūn (Sura 68), mientras que en la segunda sigue el orden inverso, metafísicamente ascendente, aunque numéricamente descendente, remontándose desde la nūn hasta el alif.

Así se completa, como en la Epístola de la Interpretación (Risālat al-Ítibār), escrito del cual hablaré a continuación, el ciclo de la manifestación descendente y la interpretación ascendente, la catábasis y la anábasis: al descenso de la revelación corresponde el ascenso del intérprete en el viaje hermenéutico. El comentario de Ibn Masarra comienza por el principio del texto coránico y, como un círculo inclusivo que no concluye, vuelve a remontarse al principio.

\section{La Risālat al-I'tibār o 'Epístola de la interpretación':}

Titulado así según el manuscrito, este escrito es, en principio, la misma obra citada por Ibn al-Abbār con el título alternativo de Kitāb al-Tabṣira (Libro del esclarecimiento) ${ }^{26}$. Como la anterior, tiene una gran importancia para el estudio de la

\footnotetext{
${ }^{26}$ Ibn al-Abbār, Takmila, ed. Codera, n 113. En traducción de Asín: “Cuando Ibn Masarra compuso su Libro de la explicación perspicua (Kitāb al-Tabșira), dado que no permitía sacar copias de ninguno de sus libros hasta que no lo corregía durante todo un año...". V. Abenmasarra, p. 49, nota 1. Esta noticia subraya el cuidado que ponía el autor en la corrección de sus escritos.

Sobre la Risālat al-Itibāar, v. P. Garrido, "Edición crítica de la Risâlat al-I'tibâr de Ibn Masarra de Córdoba", Miscelánea de Estudios Árabes y Hebraicos. Sección Árabe-Islam, Universidad de Granada, nº. 56 (2007), pp. 81-104.
} 
relación entre mística islámica y neoplatonismo, así como para la historia del pensamiento en al-Andalus.

La Epístola de la interpretación es, fundamentalmente, una exposición de la finalidad del ser humano en la creación: su función cognitiva. El ser humano puede comprender los signos de Dios por medio de la interpretación de lo que Dios ha revelado. El perfeccionamiento de la anagogía o interpretación espiritual (ítibār) del significado de los seres conduce al entendimiento, purificado e inspirado, hasta el conocimiento de las verdades primeras, de la divina Unidad y del misterio de la Esencia trascendente.

Ibn Masarra no sólo propone en la Epístola la conveniencia de la interpretación, sino que señala la obligación que, por imperativo divino expresado en el Corán, tienen los musulmanes de reflexionar sobre los signos de la creación y la Escritura, la ineludible responsabilidad de interpretar personalmente, con el propio esfuerzo de preparación y reflexión, la Palabra que Dios ha dirigido al corazón de cada ser humano. En definitiva, la interpretación es un ejercicio personal intransferible, un viaje hermenéutico en la revelación que no cabe delegar, aunque eso sí, un recorrido en que el peregrino sigue los pasos inspirados de los profetas.

La noción fundamental que subyace a todo el pensamiento de Ibn Masarra, confiriéndole una manifiesta unidad de fondo, es esta categoría esencial de Libro revelado. El Libro, como sucede también en los esoterismos de las otras tradiciones escriturarias y en el sufismo en general, tiene dos dimensiones: por un lado, es el Libro exterior del cosmos, el Libro de la naturaleza, el Libro universal de lo creado; por otro lado, es la Escritura que transcribe la revelación, es el Libro de la recitación que transmite el Enviado, el Libro que contiene las claves de la interpretación, cifra y síntesis de todos los posibles, explicación de todo lo existente.

Entre ambas dimensiones, el ser humano es el intérprete que interioriza el universo en su contemplación y articula la Palabra, exteriorizándola, en su recitación. El corazón del intérprete realiza así la unidad esencial de estos dos aspectos del 
Libro, al tiempo que constituye su tercera dimensión: el Libro interior de los signos del alma.

En esta obra nos encontramos con un concepto de entendimiento, razón o intelecto ('aql), asociado a las nociones de corazón, pureza, inspiración, visión interior y proximidad a Dios. La razón no procede fría y mecánicamente por una serie de silogismos que, por inferencia, formulados correctamente según ciertas premisas lógicas, conducirían automáticamente a las verdades primeras. Ibn Masarra nos propone una 'razón contemplativa', orientada por la revelación. Un 'entendimiento inspirado' que viene a coincidir con la Palabra porque dimana de ella y se conforma a ella. La reflexión del intérprete orientado consiste justamente en seguir los pasos del Profeta, remontándose por la vía de la revelación.

No invita el autor en esta epístola a la libre reflexión de un librepensador, sino a la personal interpretación que cada receptor de la revelación ha de realizar para ascender por la escala del modo particular que le corresponde en función del grado que alcanza su recitación, es decir, su comprensión, su interiorización, su actualización del Libro.

\section{[Obras perdidas]}

\section{El Compendio de la Mudawwana de Mālik:}

De esta obra se afirma lo siguiente: “[Ibn Masarra] había dispuesto las cuestiones de la Mudawwana mālikí, pilar de la sunna, por concomitancias, dividiéndolas según se las requiere con la más clara traza, y produciendo unas secciones extractadas excelentes que son declaradas unánimemente, hasta por sus oponentes, como mejores, más resumidas y claras que cualquier otro compendio de dicha obra" 27.

27 V. Viguera y Corriente, Crónica... [Ibn Hayyān, Muqtabas V], 11-12; y Fierro, Heterodoxia, p. 115. 
En el terreno del derecho, por su vínculo con sus maestros mālikíes conocidos, en particular Ibn Waḍḍāh, por su formación andalusí, y por su particular dedicación a esta obra de Mālik, Ibn Masarra aparece, pues, como un mālikí.

\section{El Tawhīd al-mūqinīn o 'Profesión de Unidad de los que tienen certeza':}

Este título sólo se conoce por una referencia contenida en el comentario del sufí Abū Ishāa Ibn al-Mar’a, contemporáneo de Ibn 'Arabī y maestro del también murciano Ibn Sab'īn, al Iršād de al-Ŷuwaynīien.

\section{El Kitāb al-Tabȳ̄n o 'Libro de la clarificación':}

Título conocido únicamente por la mención que de él hace Šams al-Dīn alQurțubī (m. 671/1173) en su Tadkira ${ }^{29}$. Según al-Qurțubī, esta obra contiene un hadiz sobre el Día de la Resurrección que fue transmitido a Ibn Masarra por su padre y por Ibn Waḍ̣̂āḥ30.

Por afinidad de términos, este título podría también ser una variante del $K$. alTabșira o R. al-Itibār. De hecho, en esta obra se usa en dos ocasiones significativas la forma $\mathrm{V}$ (tabayyana) de la misma raíz léxica de tabyīn. No obstante, en este escrito no se cita ningún hadiz relacionado con la Resurrección, ni siquiera se emplea propiamente el término resurrección.

Sin embargo, en el K. Jawāṣs al-ḥurūf sí se cita un hadiz que no aparece en los repertorios más conocidos y pudiera ser el hadiz en cuestión, aunque en el texto, tal como nos ha llegado, no se dice nada acerca de los posibles transmisores. Explica allí Ibn Masarra (ms. Chester Beatty 3168, p. 132) lo siguiente: “Se ha trasmitido que el Profeta -Dios lo bendiga y salve- dijo: “Se dirá el Día de la Resurrección a quien recita

\footnotetext{
${ }^{28}$ V. Massignon, Recueil de textes, 70; Ramón Guerrero, "IBN MASARRA", BA, 4, p. 150; Addas, op. cit., p. 916 y nota 35.

29 Šams al-Dīn al-Qurțubī, al-Tadikira fì aḥwāl al-mawtà, Beirut, s. d., p. 341.

${ }^{30}$ Cf. Addas, op. cit., p. 913.
} 
el Corán: 'Recita y asciende, pues te encontrarás en el último grado [el más elevado que alcance tu recitación]".

En Jawāṣ̣ al-ḥurūf se emplea el término tibyān (forma II al igual que tabyīn, con idéntico significado) en la primera página del tratado (ms., p. 130), donde dice el autor: "Cuando Dios [...] envió a Su Profeta para que llamara hacia Él [a los hombres] e hizo descender como guía hacia Él Su Libro, haciendo de él una clarificación (tibyān) y una exposición (tafșill) de todas las cosas...". Si alguna copia perdió el título de portada -que en el texto no se menciona-, pudo suceder esta sustitución.

En cualquier caso, a falta de pruebas decisivas y dado que según algunas fuentes (como la noticia de Ibn Ḥārit al-Jušanī que a continuación se traduce) Ibn Masarra escribió muchas obras, el K. al-Tabyīn ha de considerarse, en principio, como título de una obra diferente.

\section{[Obra apócrifa]}

\section{El K. al-Garīb al-muntaqà min kalām ahl al-tuqà:}

El único manuscrito conocido de este amplio tratado, atribuido a Ibn Masarra, ha sido dado a conocer por el investigador turco Mehmet Bardackı en su Tesis Doctoral inédita como obra del autor cordobés. Sin embargo, diversas fuentes andalusíes, en particular la Gunya del célebre Qāḍī 'Iyāḍ de Ceuta31, revelan que, en realidad, el Muntaqà es obra del sufí Ibn Jamīs al-Yāburī de Sevilla (m. 503/1109-10), contemporáneo de 'Iyāḍ, como se explica en detalle en los escritos que a este tema he dedicado ${ }^{32}$.

\footnotetext{
${ }^{31}$ V. 'Iyāḍ, al-Gunya: Fihrist šuyūj al-qāḍ̄̄ 'Iyād, ed. Māhir Zuhayr Ŷarrār, Beirut, 1982, pp. 92-94, no 28.

32 V. P. Garrido, "IBN MASARRA", en J. Lirola Delgado y J. M. Puerta Vílchez (ed.), Biblioteca de alAndalus: De Ibn al-Labbāna a Ibn al-Ruyūlī [Enciclopedia de la Cultura Andalusí, I] 4, (Almería: Fundación Ibn Tufayl de Estudios Árabes, 2006), n 788, pp. 150-154; y P. Garrido, “Sobre el Kitāb al-Garīb al-
} 


\section{NOTICIA SOBRE IBN MASARRA EN LA OBRA $A J B \bar{A} R A L-F U Q A H \bar{A}$ DE IBN Ḥ̂ĀRIT AL-JUŠANī}

La noticia que de Ibn Masarra nos brinda Muḥammad Ibn Ḥārit al-Jušan̄̄ (m. 361/971), coetáneo del autor, aunque más joven, en su obra Ajbār al-fuqahä wa-lmuhaddițin (Historia de los alfaquíes y tradicionistas de al-Andalus), constituye una fuente importante -entre otras cosas por ser muy temprana- que no se ha tenido particularmente en cuenta, ni se ha traducido y comentado en su integridad, que yo sepa, en estudios previos sobre Ibn Masarra ${ }^{33}$. Creo que esto se debe a que no contiene mucha información técnica específica, tal como títulos de obras o mención de viajes y encuentros con otros personajes. Parece oportuno, sin embargo, prestarle aquí la debida atención. Para ello, traduzco primero el texto completo de la noticia que dice así34:

\section{Traducción}

“El método doctrinal ( $\mathrm{madhad}$ ) de Muhammad Ibn Masarra consistía, en cuanto a las obras ('amal), en la práctica de la abstinencia ascética (zuhd) y el recogimiento

muntaqà min kalām ahl al-tuqà de Ibn Jamīs de Évora, atribuido a Ibn Masarra", Al-Qanțara, Madrid, en prensa.

${ }^{33}$ Asín no cita esta noticia de Ibn Masarra contenida en Ajbār al-fuqahä, obra que, al parecer, no tuvo ocasión de consultar, pero sí cita el manuscrito de otra obra de al-Jušanī, la Historia de los cadíes de Córdoba, conservado en la Bodleyana de Oxford (v. Abenmasarra, p. 43, nota 1, y p. 188, nota 1), cuya edición y traducción preparaba Julián Ribera. También recoge otra noticia que Ibn 'Idāâ̄ transmite de al-Jušanī, según la cual éste se encontró con Ibn Masarra en una clase impartida por el alfaquí Aḥmad b. Naṣr, continuador de Ṣaḥnūn. V. Asín, op. cit., p. 45 y nota 1.

Más tarde, la noticia de Ajbār al-fuqahä se refleja parcialmente en E. Lévi-Provençal, "A propos de l'ascète philosophe Ibn Masarra de Cordoue", Orientalia Suecana, XXVIII, Dic. 1954, pp. 75-83.

${ }^{34}$ Muḥammad Ibn Ḥārit al-Jušanī (m. 361/971), Ajbār al-fuqahä wa-l-muhaddițīn (Historia de los alfaquíes y tradicionistas de al-Andalus), estudio y ed. de M. L. Ávila y L. Molina, Madrid: CSIC-ICMA, 1992, nº. 209, p. 178. Véase también la obra de Ibn Ḥārit al-Jušanī (Aljoxaní), Historia de los jueces de Córdoba (Tảrīj quḍāt Qurțba), ed. y trad. de J. Ribera, Madrid: Imprenta Ibérica, 1914; Historia de los jueces de Córdoba (reedición de la traducción), Granada: Editoriales Andaluzas Unidas, 1985. 
(inqibạd ), y en cuanto a la ciencia ('ilm), en la práctica del pensamiento racional (nazar) y la indagación (istinbāt ). Era docto y sagaz en las [diversas] ciencias [tradicionales], en [todas] las cuales llegó a ser experto.

Compuso muchos escritos (allafa... kutuban katīira) [en los que trata] acerca de la corrección de las obras (taṣhịh al-a'māl) conforme a la vía de la devota conciencia (madhab al-tuqà), acerca de la práctica de la atención interior (muḥāsabat al-nufüs) conforme a la sincera veracidad $(s i d q)$ y acerca de la importancia de vigilar los diversos modos de la falsedad y la impostura [espiritual] (al-tanbīh 'alà wuŷūh almudāhana wa-abwāb al-mujāada'a) sirviéndose de la develación (kašf́) y el análisis deductivo $(\text { tafr } \vec{\imath})^{35}$.

$\mathrm{Su}$ discurso en sus obras se asemeja al discurso de sus predecesores (mutaqaddimūn) entre la gente de ciencia esotérica (ahl al-ilm al-bātin), como Dū 1-Nūn al-Ijmīmī [al-Miṣrī] ${ }^{36}$, Abū Sa ${ }^{(\overline{1}} \mathrm{d}$ al-Askāf ${ }^{37}$ y otros conocedores de esa ciencia afines a ellos.

\footnotetext{
${ }^{35}$ Cabe considerar la posibilidad, que me ha sugerido María Isabel Fierro, de que estas referencias temáticas aludan a títulos de escritos de Ibn Masarra sobre esos mismos temas. Pudiera así, según esa hipótesis, haber escrito una obra con un título semejante a Taṣhḥh al-ámāl 'alà maḍab al-tuqà, otra con un título como Muhāsabat al-nufüs... y otra con un título parecido a al-Tanbīh 'alà wuŷūh al-mudāhana $w a-a b w a \bar{a} b$ al-mujāda'a... En la noticia estas expresiones se refieren claramente a temas y no a títulos, pero no ha de descartarse que, como en ocasiones sucede en otras noticias de repertorios biobibliográficos con expresiones afines, puedan remitir a escritos concretos.

${ }^{36}$ V. Ibn 'Arabī, La maravillosa vida de Dū l-Nūn, el Egipcio, Murcia: ERM, p. 19. También cabe leer más dialectalmente Ajmīmī, es decir, de la ciudad de Ajmīm, situada en el Alto Egipto, a unos $460 \mathrm{~km}$. de El Cairo.

${ }^{37}$ Tal vez se trate del sufí Abū Sa'īd Aḥmad b. Muḥammad b. Ziyād Ibn al-A'rābī de Basora, el discípulo de al-Ŷunayd de Bagdad, a quien Ibn Masarra conoció en La Meca. No obstante, no he encontrado el apelativo de al-Askāf que aquí aparece. V. Asín, Abenmasarra, p. 47, nota 1. Sobre este importante personaje, v. Manuela Marín, "Abū Sa'îd Ibn al-A'rābī et le développement du soufisme en al-Andalus", Revue des Mondes Musulmanes et de la Méditerranée (2004), pp. 28-38.
} 
Sus obras, para quien profundiza en su lectura, dan testimonio [de que lo que el autor expone en ellas es el fruto] de lo que llegó a conocer por su propia develación (muțāláa), no la mera transmisión de aquello que de las ciencias [tradicionales] había aprendido ${ }^{38}$.

Dijo [también el autor,] Muḥammad: La gente, con respecto a él [a Ibn Masarra], se divide en dos grupos [según su parecer]: Un grupo (firqa), para quienes resulta manifiesta su excelencia en el conocimiento y su sinceridad en la ascesis, considera que llegó a alcanzar la condición de guía (imāma) tanto en el conocimiento [de Dios] como en [la práctica de la vía de] la abstinencia (zuhd). Otro grupo, a quienes parece evidente que sus doctrinas sobre [el cumplimiento de] la promesa de recompensa y la amenaza de castigo [por parte de Dios en el Más Allá] (al-wa'd wa-l-wa(̄d), así como su interpretación simbólica $\left(t a^{\prime} w \bar{l} l\right)$ de las aleyas del Corán, [se apartan de] ${ }^{39}$ las tradiciones proféticas (sunan), y se alejan de las ciencias reconocidas (al-ulüm alma'lüma) en la tierra de al-Andalus que se ajustan a la doctrina de la instrucción tradicional (taqlīd) y la admisión de la norma sin reservas (taslīm), lo difaman acusándolo de innovación (bid' 'a).

\footnotetext{
38 Más literalmente: “Sus libros... dan testimonio de que tenía un conocimiento propio [es decir, resultado de su hallazgo personal] que no es lo que de las ciencias había aprendido".

39 Hay una laguna en el texto, de modo que el texto que restituyo entre corchetes es sólo una interpretación posible. Esto parece aludir al hecho de que se atribuyeron al autor doctrinas mu'tazilíes sobre la interpretación figurativa $\left(t a^{\prime} w \bar{l} l\right)$-entiéndase, la interpretación abstracta de las aleyas que contienen imágenes antropomórficas, con negación de cualquier posibilidad de percepción sensible de Dios en el Más Allá, lo cual no aparece en modo alguno en los escritos conocidos de Ibn Masarra-, y sobre el inexorable cumplimiento de las promesas y amenazas divinas (infā $\underline{d} a l$-wa'd wa-l-wa' $\bar{l} d$ ), acerca de lo cual tampoco dice nada Ibn Masarra en los escritos que conocemos. Véase la sucinta presentación que de éstas y otras doctrinas mu'atazilíes, basándose en Šahrastān̄̄, hace M. Sells, Early Islamic Mysticism, p. 308 y ss. Asín dice, por el contrario, que Ibn Masarra habría afirmado que no tenían realidad alguna los castigos del infierno (Abenmasarra, p. 42, donde remite a Șă̄id e Ibn al-Qifțī), lo cual no se corresponde con las doctrinas mu'tazilíes al respecto, ni siquiera con la doctrina de los ŷahmíes, quienes profesaban que las moradas del Paraíso y el Infierno tendrán un fin. V. Sells, op. cit., p. 314 .
} 
Muhammad Ibn Masarra, alejándose del área urbana de Córdoba, se fue a un lugar [aislado] de su serranía, donde permaneció apartado (inqabaḍa) de la mayoría de la gente. Falleció en el mes de šawāl del año 319 h. [= 931]”.

\section{Comentarios al texto de al-Jušanī}

El autor de la noticia, que al parecer conoció personalmente a Ibn Masarra ${ }^{40}$, mantiene una posición respetuosa y favorable hacia él, aunque no deja de reflejar, con equilibrado distanciamiento, las posturas contrarias de sus contemporáneos, admiradores o detractores, con respecto al pensador cordobés. De hecho, como ya señaló Lévi-Provençal ${ }^{41}$, este autor originario de Qayrawān, instalado luego en Córdoba, fue el primero en dejar constancia de estas dos tendencias.

El alejamiento de la urbe y la ascética renuncia al mundanal ruido son actitudes frecuentes en la espiritualidad islámica de la época por las cuales no se critica a Ibn Masarra. Sin embargo, se le atribuyen algunas doctrinas de inspiración mu'tazilí que no se conforman al taqlīd de los ulemas andalusíes. Tal vez la defensa del pensamiento racional y de la iniciativa en la interpretación y la indagación personal, reflejadas en la R. al-I'tibār, distinguieron a Ibn Masarra en el contexto andalusí y bastaron para suscitar el recelo de los alfaquíes que, comprometidos con las instituciones centrales, buscaban una unanimidad sin resquicios.

Usa Ibn Ḥārit al-Jušan̄̄, con respecto al pensamiento de Ibn Masarra, el polivalente término istinbāt que se presta a diversas interpretaciones. Por su raíz léxica significa buscar en las fuentes o profundizar en los misterios, pero designa también la hermenéutica del texto revelado y la búsqueda filosófica de las verdades primeras. A diferencia del término nazar, empleado repetidas veces en la R. al-Itibār, Ibn Masarra no emplea el término istinbāt o sus variantes morfológicas en sus obras conocidas.

\footnotetext{
40 Véase supra cap. I, p. 46, nota 16.

41 V. Lévi-Provençal, op. cit., pp. 77-78.
} 
Al referirse a los temas de sus escritos comenta que estos fueron numerosos, añadiendo que en ellos trataba de la ciencia esotérica, al modo de los grandes sufíes que le precedieron, pero que lo hizo de modo personal, a partir de su propia develación (muțāla'a).

Hay en todo ello un reconocimiento explícito de su condición de maestro espiritual. Ibn Hạarit parece dar a entender también implícitamente que el pensamiento masarrí está vinculado a la cadena de iniciación de los citados sufíes orientales.

Al comentar que quienes le consideran sabio y virtuoso le atribuyen la condición de imām tanto en la ciencia (no especifica aquí si sólo tradicional o también inspirada) como en la práctica contemplativa (así entiendo aquí el término zuhd, que en general se interpreta sólo como ascesis y vía purgativa), refleja la alta estima en que se tenía su autoridad entre quienes le eran favorables. 